\title{
Out of Africa: Tocqueville's Imperial Voyages
}

\section{Citation}

Welch, Cheryl. 2011. "Out of Africa: Tocqueville's Imperial Voyages." Review of Middle East Studies 45(1): 53-61. Paper written for Liberty Fund Conference on "Tocqueville's Voyages," Jan. 9-11, 2009. Chicago, IL.

\section{Published Version}

http://www.jstor.org/stable/23057106

\section{Permanent link}

http://nrs.harvard.edu/urn-3:HUL.InstRepos:13064249

\section{Terms of Use}

This article was downloaded from Harvard University's DASH repository, and is made available under the terms and conditions applicable to Other Posted Material, as set forth at http:// nrs.harvard.edu/urn-3:HUL.InstRepos:dash.current.terms-of-use\#LAA

\section{Share Your Story}

The Harvard community has made this article openly available.

Please share how this access benefits you. Submit a story.

Accessibility 


\title{
Out of Africa: Tocqueville's Imperial Voyages
}

\author{
Cheryl B. Welch \\ Department of Government, CGIS K151A \\ Harvard University \\ 1737 Cambridge Street \\ Cambridge, MA 02138 \\ Phone: $617-495-5855$ \\ Fax: $\quad 617-495-0438$ \\ Email: cwelch@gov.harvard.edu
}

\section{Introduction}

As a member of the Chambre during the July Monarchy, Tocqueville often reminded his fellow deputies that seeing new worlds prevents intellectual self-delusion and corrects political judgment. In Democracy in America, as well as in his parliamentary speeches and pamphlets, he drew heavily on the legitimacy conferred by "eye-witnessing." Indeed, the authority of the first-hand, filtered through an acute intelligence and expressed with deceptively classical simplicity, became Tocqueville's writerly signature. There has been much controversy, however, about the extent to which Tocqueville saw America primarily through European lenses, and about whether he actually learned anything of importance there. It is one of the virtues of the Nolla critical edition of the Democracy, now made available to English readers, to show that viewing the United States first hand — its culture, society, politics, and predicaments — was decisive for the formation of his view of democracy as well as for his self-presentation as a truth-telling traveler. ${ }^{2}$ 
"Seeing Africa" was to play an analogous role in Tocqueville's writing and political rhetoric. In his first letter on Algeria, written to bolster his parliamentary candidacy, Tocqueville notes that he has not been to Africa, though he is not so foolish as to boast of it. ${ }^{3}$ After he had visited Algeria, he did not fail to exploit this privileged access in his speeches and reports ("if the Chamber will permit me to speak only of my own personal experience. . . I am profoundly convinced of the opposite"). ${ }^{4}$ In this essay, I ask how we should evaluate Tocqueville's encounter with Africa within the context of his larger voyage into the territory of modern democracy. What were his justifications for the imperialist move into Africa? What lessons did he (and should we) draw out of this theoretical voyage?

\section{Into Africa: Tocqueville's imperial voice}

Compared to other nineteenth-century European imperial ventures, the French conquest of North Africa was relatively long, violent, and destructive. After displacing the Turks in 1830, France was at first unsure about how to consolidate her position. This indecision changed, however, with the emergence of significant resistance under Abd-elKader, a charismatic young religious and political leader who united Arab forces in the mid 1830s. Eventually the French decided to establish military dominance over the entire territory, a decision leading to a costly war that ended only in 1847 . The struggle for control over Arab territory—-the term of art began to be "pacification"—was entwined with an ambitious but "anarchical" policy of European colonization. ${ }^{5}$

For many years, the war in North Africa appeared to be a matter of one step forward, two steps back. In 1840, however, Governor-General Thomas Bugeaud formalized the goal of total conquest and systematized the war's sporadically brutal 
tactics. Under his command, mobile columns of French troops deliberately ravaged all territory not under French control in order to prevent Arabs from sowing, harvesting, and grazing. ${ }^{6}$ The aim of these successful razzia was to instill terror and destroy tribal cohesion by taking war to the civilian population in Arab villages. The predictable result was disease, famine, and eventual Arab disaffection from the war effort. ${ }^{7}$ Beyond the use of razzia, Bugeaud defended controversial episodes of mass killings of civilians by French officers as salutary episodes of terror that would hasten the end of the war. ${ }^{8}$

In the seventeen years until conquest was attained, there was a high degree of self-consciousness among members of the French political class about the aims and conduct of this colonial war. In pamphlets and in the Chamber of Deputies they debated the potential value of any North African possession, the wisdom of colonization, the organization of the settler colony, the rationality of apparently ever-expanding military operations, the morality of French conduct of the war, the frightening "barbarism" of the enemy, and the nature of military/civilian relations in a democratic regime. Tocqueville was a keen participant in these debates.

\section{A. Tocqueville and "la grande affaire d'Afrique"}

Shortly after the dispatch of French troops to blockade (and eventually to seize)

Algiers, Tocqueville discussed this expedition in letters to his brother Edouard. Like most of the French political class, he believed that the alleged trigger - the need to avenge a slight to the French envoy - was merely a cynical ploy by Charles X to shore up the Government's popularity before parliamentary elections. ${ }^{9}$ More important for his subsequent defense of French policy in Africa, however, Tocqueville was struck by the tendency of this incident to mute petty partisanship. There was, he noted, "truly a 
national spirit in the way in which this question has reunited opinions." ${ }^{10}$ Although his trip to America and the writing of the two Democracies absorbed much of his energy during the next decade, Tocqueville continued to follow events in Africa closely, even thinking briefly of settling there. ${ }^{11}$

In 1837 Tocqueville launched his first election campaign by writing two "Letters on Algeria" that acknowledged many mistakes in the French conduct of the war, but nevertheless looked forward to a revitalization of North Africa, to "two peoples of different civilizations [managing] to refound themselves as a single whole." ${ }^{\prime 2}$ He painted an optimistic portrait in which the French would hold North Africa with the willing consent and support of the indigenous populations. A year later he began to read the Koran, hoping to find points of affinity between Muslim and Christian doctrine that would ease such a joint venture. ${ }^{13}$ Tocqueville traveled to Algeria for the first time in May of 1841 as part of an official parliamentary group, and on his return wrote a substantial "Travail sur l'Algérie," concluding grimly that his former hope to fuse the two populations had been a chimera. ${ }^{14}$ Now his focus was on the need to quell resistance as quickly as possible, on the morally dubious measures that were necessary for such a victory (a war in which "we burn harvests, ... empty silos, and finally. . . seize unarmed men, women and children”), on the relationship between domination and colonization, and on the pressing challenges involved in implanting a successful European colony. ${ }^{15}$

It is clear from these writings that Tocqueville was a steadfast proponent of French emigration to Africa to create a settler society, and that by 1837 he was convinced of the need to control a substantial part of the territory (in contrast to limited or restrained occupation) in order to secure a zone of colonization. Both were contested policies 
among the center left groups in the Chamber with which he was loosely aligned. For the most part, he supported the Ministry on Algerian policy, even though he remained a sharp critic of its implementation. He supported Bugeaud's scorched earth policies as necessary to break the hold of Abd-al-Kader on the tribes and had by 1840 completely given up on any "quick, brilliant, honorable" end to the war. ${ }^{16}$

In a characteristic reach for a comparative perspective, Tocqueville began in the early 1840 s to envision writing several articles on "the causes that produced and that sustain the astonishing greatness of the English in India." This subject was central, he wrote in a letter to Buloz, since "the crux of all great European affairs lies in Asia. This is particularly so for us now that we have the colony of Algeria." ${ }^{\prime 17}$ The implicit contrast between successful Britain and struggling France, bogged down in a battle to pacify North Africa and regularize her rule, is clear in the organization of his reading notes on India and in the draft of the first part of this projected work. ${ }^{18}$

Tocqueville gave his only major speech on Algeria in June of 1846, followed by a second three-month trip to Africa. As victory finally appeared imminent, and driven by the desire to "see and judge African affairs for myself," he toured Algeria from October to December $1846 .{ }^{19}$ His study of the country during this trip, as well as the perspective on arcana imperii he had gained by his study of India, are reflected in the two long parliamentary reports that he wrote in 1847 as the rapporteur of a legislative committee on the organization of the peace and the future of the colony.

In what ways are Tocqueville's journeys into Africa analogous to those earlier trips to America, England, and Ireland that provided much of the raw material for Democracy in America? In 1841, until illness forced his return from Algeria to France, 
Tocqueville kept a diary in which he recorded long passages from his interlocutors' conversations, and his own vivid first impressions.

First appearance of the town: I have never seen anything like it. Prodigious mix of races and costumes, Arab, Kabyle, Moor, Negro, Mahonais, French. Each of these races, tossed together in a space much too tight to contain them, speaks its language, wears its attire, displays different mores. This whole world moves about with an activity that seems feverish. The entire lower town seems in a state of destruction and reconstruction. On all sides, one sees nothing but recent ruins, buildings going up; one hears nothing but the noise of the hammer. It is Cincinnati transported onto the soil of Africa. ${ }^{20}$

He also reported in a series of letters to friends and family. As in his earlier voyages, we find him grilling his informants, always returning to the central questions that preoccupy him, and trying out formulations of ideas that later appear in his manuscripts and published works. He is at once observer, thinker, and potential pedagogue. What he says at the beginning of Democracy in America (in a passage suppressed in the published edition) will be quite true of his Algerian texts as well: "the work that you are about to read is not a travelogue. ${ }^{, 21}$ But when he visited Boston, London, or Dublin, Tocqueville was primarily a private citizen and a passionately curious intellectual, on the lookout for ways to refine and elaborate his general idées mères about the effects of the democratic revolution and its impact in different societies. In Africa he was not merely a citizen but a representative of France, not just an intellectual but an official partly responsible for solving an immediate political problem. His informants, found disproportionately among 
French civil and military officials, rather than among colonists or indigènes, supply a narrower type of knowledge.

America and England appear in Tocqueville's texts as teeming laboratories for studying modern political culture and for identifying the possible interactions among ideas, institutions, and political action. They offer a fertile mix of familiarity and distance: close enough to be brought into the same comparative frame, far enough away to induce analytical clarity through a productive sense of wonder. Africa, on the other hand, seems less an open territory over which his thought roams freely than a restricted field of interrogation or, as Jennifer Pitts has put it, "a laboratory for ideas of governance." ${ }^{22}$ It is not that he is unwilling to face uncomfortable facts- - he details the failings of France with sometimes brutal clarity—but the range of his imaginative sympathy is reduced. Tocqueville does not forget that Africa is there to be mastered even more than understood.

As Tocqueville's writings on empire have become more available in translation, and as both Anglophone and Francophone political theorists have begun to grapple with the transnational aspects of liberal democratic theory, scholars have increasingly puzzled over the dissonance between Tocqueville's imperial and liberal voices. One fault line in these debates centers on the question of whether the apparent tension between Tocqueville's defense of French imperialism and his liberalism is illusory or real. Tzvetan Todorov and Stéphane Dion, for example, construe Tocqueville as a proponent of realpolitik who believed that the claims of justice stopped at national borders. By projecting the liberal rights of individuals onto sovereign national entities acting in an anarchic international state of nature, Tocqueville could put French national interests first 
without inconsistency. Thus there is no real paradox to be explained. ${ }^{23}$ Tocqueville, however, was never a liberal social contract theorist in the classical sense. Moreover, he always maintained that national majorities are not morally free to do whatever they choose either within or beyond their borders. Thus this interpretation rather implausibly ignores a wealth of textual evidence. In contrast, beginning with Melvin Richter's classic article "Tocqueville on Algeria," more careful readers have perceived a real interpretive conundrum in Tocqueville's inconsistent universalism. What Roger Boesche has recently called the "dark side of Tocqueville," his apparent readiness to ignore the insights of his own liberalism, has called for explanation and contextualization. ${ }^{24}$ How did he square his commitment to liberty with his embrace of permanent colonial domination?

\section{B. Arguments for Empire}

Tocqueville himself does not directly address the normative issues of whether and when the aggression of one nation against another can be considered just. On the contrary, he assumes that conquest is a fact of political life, both in aristocratic and democratic times. This assumption does not mean, however, that one cannot distinguish morally better and worse types of domination. In his various discussions of the Spanish conquistadores, the Anglo-American encounters with indigenous peoples, and the English in Ireland, the following distinctions emerge. The conquered may be assimilated and treated humanely (good) or shunned and exploited (bad), or driven away, even exterminated (very bad) ${ }^{25}$ One may also condemn deliberate bad faith and warfare that is more barbarous than necessity requires. These moral judgments sporadically surface in his writings on Algeria and India, but for the most part he ruthlessly disregards them, 
defending the war against the Arabs and the invasive colonization project as vital for France. $^{26}$

Scholars have identified three kinds of arguments in Tocqueville's texts justifying the conquest of Asian or African territories by European powers: the requirement of a great power to maintain international standing by projecting "grandeur," the beneficial effects on domestic politics and nation-building, and a duty to civilize the uncivilized (the infamous mission civilisatrice). The first two, closely linked in his mind, are quite evident in Tocqueville's discussions of the French in North Africa and the English in India. The third, however, is a trickier business. In context, Tocqueville appears the most tepid of civilizers. Given his rich sociological appreciation of the persistence of moeurs, and his dread of imposing uniformity on plurality, this hesitance to embrace a civilizing mission is not surprising.

\section{International imperatives}

From his first speech in the Chamber (expressing outrage and even threatening war because of the pointed exclusion of France from the settlement of the eastern question) it was clear that Tocqueville believed that the primary goal of French foreign policy must be to reclaim her rightful position in Europe. The debacle of the revolutionary and imperial years had damaged France's standing among the great civilized nations. To play this role again she needed to project her power on a par with the other great nations, especially England. ${ }^{27}$ Success in Algeria was key to this parity. The great project of launching a civilized colony in Africa would help France reclaim her

role as an equal arbiter of Europe's destiny. ${ }^{28}$ Indeed, if France abandoned North Africa, then another civilized power would move into the vacuum and would reap any potential 
advantages in power and prestige. By the late 1830s Tocqueville is convinced that retreat would be ruinous. To withdraw from Africa would disgrace France and weaken her beyond repair in Europe, which would regard this action as "yielding to her own impotence and succumbing to her own lack of courage. ${ }^{29}$ As Hugh Brogan has noted, this was the logic of Pericles: "“you now hold your empire down by force; it may have been wrong to take it; it is certainly dangerous to let it go." ${ }^{30}$ The argument for French grandeur, however, was not merely a matter of national hubris. Tocqueville believed that France had an obligation to assume the responsibilities of a great power, to set civilized norms, to arbitrate disputes, and to counteract the influence of other powers. Reestablishing the preeminence of France would indirectly promote the interests of Europe and the stability of the international system. ${ }^{31}$ To abandon this duty was shameful.

\section{Domestic drama}

A second reason for persisting in Algeria was the impact of the French colonizing venture on domestic French politics, in particular the provision of a dramatic common focus and the diffusion of class rancor. Drawn into an imaginative vision that transcended petty self-interest, all citizens could find in this expansion into a new world a patriotic renewal of faith in la grande nation. Tocqueville, of course, believed that this capacity to subordinate personal interest to the good of the whole was the sine qua non of a free people. He was struck again and again by the ability of the English to sustain such crossclass cooperation and he saw a common pride in their Indian "possession" as an important ingredient in this mix. ${ }^{32}$ Unlike some on the left, Tocqueville doubted that France could successfully expand towards the Rhine, a foreign policy course that would cause Europe to close ranks against her. But the conquest and colonization of Algeria 
offered a glorious outlet. André Jardin has commented that Tocqueville saw the African venture as a way to unite the political class (le pays légal) with the rest of the country (le pays réel). ${ }^{33}$ Projecting French power into the world indirectly built domestic bridges.

\section{A civilizing mission?}

A third potential argument justifying French domination over the Arabs and Kabyles of North Africa, and European rule over "barbarous" countries in general, is the right and duty of the advanced to rule the backward in order to civilize them. All careful readers of Tocqueville have noted that he thoroughly rejected racial arguments for the inferiority of a people, but it is just as clear that he accepted cultural and historical ones. He believed that peoples become enlightened at different rates, that enlightenment entails economic and social development, that development brings power, and that the power of civilized nations seduces the less civilized. These beliefs underlie Tocqueville's discussion of relations among European nations no less than his understanding of Europe's colonial diaspora. ${ }^{34}$ And in these assumptions, Tocqueville reflected a widelyaccepted theory that all peoples pass through the stages of hunting/gathering, herding, and agriculture before arriving at civilization. Adopting contemporary usage, Tocqueville often referred to hunter-gatherers as savage, while conflating pastoral and agricultural stages as barbaric or imperfectly civilized.

Tocqueville had no doubt that civilization definitively transformed the pattern of

confrontation and conflict among nations by privileging the European powers. ${ }^{35}$ But this belief in European superiority does not mean that he appealed to civilization as a defense of empire in anything like the strong manner used by English liberals or many of his French contemporaries. If a "civilizing mission" calls for the deliberate conversion of 
indigenous peoples to European civilization through education, missionary efforts, or state policy, with the aim of eventually transforming native law, custom, and religious practice, then in Tocqueville the call was faint.

In exploring the question of the ways in which Tocqueville saw the right and duty to civilize connected to European colonial rule, we first must take heed of a key distinction that runs through everything Tocqueville has to say about expansion into new worlds: the difference between domination (ruling a defeated population) and colonization (displacing or replacing a part or the whole of that population). ${ }^{36}$ There can be domination without significant colonization (for example the case of Ottoman Algeria or British India); colonization without domination (if the territory is "empty," or if the indigenous population dies out or is exterminated, as sometimes happened in North America or the Caribbean); or a combination of domination and colonization (the French in Algeria). Tocqueville's civilizing rhetoric must be understood in relation to these different sorts of imperial expansion.

\section{a. Domination tout court: Turks and Brits}

Invasion and domination of one people by another is an old story. It is what the Turks did in Algeria, and Tocqueville sometimes uses the phrase "to rule in the manner of the Turks" as a short-hand for dominating another country successfully with the tacit consent of the conquered, a consent inferred by the lack of overt resistance. Indeed, he does not always use the phrase "in the manner of the Turks" in a pejorative way. It sometimes just means the shrewd and prudent administration of a foreign country (in one's own interest to be sure) by judiciously dividing and conquering and by conciliating key members of the defeated elites. But sometimes he does seem to condemn rule "in the 
manner of the Turks." Though they were not ineffective as conquerors, the Turks were too greedy and rapacious, a result of their own barbarism. For example they collected taxes from Arab and Berber indigènes to swell the coffers of the dey, without using those taxes to defray the expenses of governing the conquered territory, to maintain roads, or to dispense impartial justice.

The British, Tocqueville notes, ruled India in the manner of the Turks - albeit as kinder, gentler Turks - and it is just this achievement that he initially admires. In his projected work on India, Tocqueville intended to capture the attention of his readers by first puncturing the myth of the supposedly great British feat in conquering the subcontinent. On the contrary, he argues, the conquest was completely understandable given the distraction of the French with revolution and war, the acquiescent nature of the major Indian religions, the indifference and self-sufficiency of Indian communes, the lack of Indian national feeling due to the caste system, the petty squabbling of Indian princes, and the familiarity of the Indians with rule by foreigners of another religion. Indeed, "the English were swept into domination of India by a current stronger than themselves." 37 What needs to be explained is something quite different: the ability of the British to organize the conquest and to govern India, despite many initial injustices and scandals, despite policies that impoverished the population, and despite such potentially disastrous mistakes as importing the complicated forms of British justice. The eventual establishment of regular and moderate government, of civilian control that was superior to the military but not itself above the law, of rule over a large diverse empire that forsook the imposition of uniformity or centralization, and of functional coordination 
between the East India Company and the British state - these are the feats worthy of study.

Tocqueville is quite clear that these achievements fall far short of bringing civilization to India. Despite pious and self-justifying rhetoric - they claim to do everything out of principle, or for the "good of the indigenous people," or for the benefit of the very princes they are attempting to conquer - the British actually rule as milder and more skillful Turks. While they do use taxes raised from their subjects to defray the expenses of governing, they do nothing to revive the country, for example by building public works. "So far the English have ruled over India for themselves and not for her." 38 Moreover, according to Tocqueville, while Indian social structures were slowly beginning to weaken, the Indians gave no sign of wishing to adopt European civilization or religion. He writes in a marginal note that India cannot be civilized while she retains her religion, and a religion "of this kind" is so tightly mixed with the social state, morals, and laws that it is impossible to destroy, maintaining its hold even after people have ceased to believe in it. To civilize one must break into this "vicious circle," a daunting and dangerous business.

Despite the British failure to bring either economic development or cultural change to India, Tocqueville holds up their ability to dominate the continent successfully as instructive for France. Having achieved her conquest of North Africa, France must not shrink from the little acts of violence necessary to consolidate it. In 1846 Tocqueville wrote a long revealing letter to General Lamoricière outlining the following possible "violences de détail" the French might adopt in Algeria to consolidate their rule. ${ }^{39}$ 
1) Turn the masses against the elites. A tried and true method of consolidating a new regime, this strategy probably would not work in Algeria, since elites had a religious hold on the people, and since the indigenous populations had not yet reached a social state that would make them susceptible to it. Tocqueville adds that such an appeal to the masses is, in any case, always dangerous.

2) Give some families individual property in exchange for their tacit support of French seizure or "purchase" of tribal lands.

3) Link the interests of some indigenous elites to the French by giving them property and power confiscated from unfriendly tribes. These elites will then become "usurpers like us," and will deflect hatred of the French onto themselves.

Though apparently callous, such measures, Tocqueville insists, correspond to the practice of all conquerors. He concludes:

In places where no revolution occurred in ownership or in the social state, a revolution did nevertheless take place in the basis of political power. The locus of power shifted. The ambition of some was used to counter the hostility of others. This was the fundamental method of the English in India. Can nothing similar be done in Africa? If I'm not mistaken, political power was constituted in Algeria as it has always been in nations that are at once aristocratic and half-civilized: the government associated itself with part of the population in order to govern the rest. With the aid of certain privileged tribes, it acted on the remainder of the population. This was the method of the Turks. I believe that in this respect they were imitated by Abd-el-Kader, who probably did no more than transfer the 
privilege from one set of hands to another. Why don't we do the same thing?

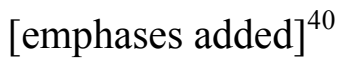

Tocqueville assumes that for a very long time France will rule over the Arab indigènes in North Africa as "better" Turks. ${ }^{41}$ I take up a more detailed discussion of his view of the fate of the indigènes below.

\section{b. Colonization}

The demands of civilized conquest—-that is, acting as better Turks—appear in Tocqueville's writings to be more arduous than awe-inspiring. France was struggling, he admitted in 1841, even to do as well as the "barbarous" Turks or the Arabs, whose actions could sometimes be construed as more civilized than those of the French. ${ }^{42}$ Much less keen on the domination of Algeria than on the founding of a new society, Tocqueville supported the conquest only because he believed it necessary for the safety and growth of a French/European colony. "Colonization is not an accessory to the thing that we are doing in Africa, it is the thing itself." ${ }^{, 43}$ In a country like Algeria, with a restive warlike population and without truly settled agriculture or well-formulated notions of individual property, domination tout court, according to Tocqueville, would be precarious and unproductive. But colonization - founding a new society where freedom could flourish—engaged his deepest instincts.

Colonization complicates the debate over whether Tocqueville believed in a civilizing mission, for some of his soaring rhetoric about the march of European civilization refers to the displacement rather than the development of populations. The valley of Metidja, he wrote from Algeria in a letter to Lanjuinais, appeared to be populated only by a few Arabs thrusting and parrying with knives. As such, it presented 
"a spectacle at once admirable and saddening. In the hands of a civilized people this immense valley would be one of the most beautiful countries on earth."44 Tocqueville found the sheer spectacle of a dynamic European people transforming the desert into a developed commercial society to be a beautiful vision; a way for the French to make a striking move into the democratic future.

\section{III: Out of Africa: lessons for democratic founders}

\section{A. Une florissante nation}

The ideal of "a flourishing nation" in North Africa filled with roads, modern communications, capitalist agriculture, and energetic and self-interested colonists

inspired in Tocqueville an awe surprisingly free from ambivalence. ${ }^{45}$ Though always guarded in his writings on free trade in the context of economic policy in France, Tocqueville enthusiastically endorses "libre-échange" and its effects in his colonial writings. Indeed, he hunts down all the economic errors committed in the European colony by misguided reformers who advocate collectivist schemes of colonization (whether military, socialist, monastic, or statist), and by military or civil officials who interfere in the economic affairs of the colony or arbitrarily suspend the rule of law. ${ }^{46}$ Unlike the English, who do not subsidize their emigrants, but merely assure them a new territory where property and contracts are safe from force and fraud, the French, according to Tocqueville, export their administrative penchant to micromanage everything, but fail to create a governmental structure with clear lines of responsibility. Indeed, the French have created a bureaucratic nightmare worse than anything found in France itself. $^{47}$ 
In his second "Letter on Algeria," Tocqueville had argued that the alleged decline of the religious motive and the rise of material interest among indigenous peoples were among the most hopeful signs for their joining the French in a new civilization. ${ }^{48}$ In the 1840s, when he had abandoned his earlier belief in these signs, he champions the cause of the economic colonists against the military, who manifest an imbecilic irritation with the colonists' desire to make money. ${ }^{49}$ From a limited military point of view, Tocqueville admired French warriors in Africa, but he also believed that they "take on distorted proportions in the public imagination" and that their influence in the colony should be restricted. ${ }^{50}$ It is not the exploits of citizen soldiers like Cincinnatus that capture his imagination, but rather the "heroic" creation of a commercial "Cincinnati transported onto the soil of Africa." ${ }^{51}$

Tocqueville focuses above all on establishing a viable agricultural colony, commercially profitable and based on the "allure of gain and comfort." ${ }^{, 52} \mathrm{He}$ is absorbed in the need to attract independent capital, circulate credit, speed up the workings of the profit motive, and open up French markets to the colonists. "[W]hen [the colonist] is not exposing his own resources or counting on himself alone, he rarely displays that ardor, tenacity, and intelligence that make capital productive." The objective is not to benefit economic interests in France (in the short term those interests may even suffer) but to create a vital economic and civic society peopled by colonists with "ardor, tenacity, and intelligence" who make both capital productive and (eventually) local civic life possible. Tocqueville's hope is that the state can create the conditions for this new society: civil and economic freedoms that will reinforce each other to create an invigorated character, "free, passionate and energetic. ${ }^{53}$ Against much evidence and against all odds, he hoped 
that a new colonial venture-less like the old French empire in Canada and Louisiana and more like the vigorous English colonies in America - might create an inspiring monument to the glory of the French. ${ }^{54}$

Some characterizations of Tocqueville's analysis of the sources of vitality in American democracy overstate the extent to which he thought civic energy flowed from public to private life, rather than in the other direction. ${ }^{55}$ In Tocqueville's America, we should remember, the qualities of independence and self-reliance needed for success in commerce tend to carry over into political life. ${ }^{56}$ Good business requires steadiness, practical shrewdness, farsightedness, the ability to calculate risk, and a determination to beat the odds. So too does free politics. The trick is to create a structure in which these spillovers are productive, in which positive economic energies are harnessed to the public good. This vision is not bound geographically or conceptually to America. Tocqueville's writings on Algeria (composed during the period of his greatest private criticism of the mediocrity, place-hunting, and individualism of the French middle-classes) remind us of the extent to which he saw economic and political liberalism both as mutually-reinforcing and in tension. When Tocqueville writes from the perspective of Algeria, where legal irregularities and military violence were the norm, the vision of a settled society that protected property and contracts takes on a positive allure. In 1841, for example, he contrasts what an ordinary citizen could expect in France-above all guaranteed property rights, settled civil law, independent magistrates, and some influence on events- - with the horror of their absence in the Algerian colony. How, he despaired, could France attract rational economic immigrants to such a "miserably anarchic" place? ${ }^{57}$ 
Tocqueville's embrace of economic civil society in Africa is all the more surprising in that the self-governing aspects of such a democratic society are muted. While he hopes that civil and political freedoms will eventually flourish in Algeriaindeed, without collective interests and actions there will be no "society"- - he condones short-term restrictions on the press, a system of advisory councils that are appointed rather than elected, and tight control over all relations with the indigenes: "the electoral system, freedom of the press, the jury. These institutions are not necessary for the infancy of societies. ${ }^{, 58}$ Tempering his enthusiasm for the potential future of the settler colony was the sober recognition that it was being formed amidst a sea of Arab enmity, and was populated by flawed immigrants whose passions could not be allowed free reign. The metropole had to police the fragile borders between two peoples, isolate the Europeans from the simmering resentment and hatred of the indigènes, and protect the natives from the aggression and intolerance of the settlers.

\section{B. Les anciens habitants de l'Algérie}

In his "First Report on Algeria," written on the eve of victory, Tocqueville speaks about the obligation of the French to govern the "old inhabitants of Algeria" with decency, that is, to provide "a power that guides them, not only toward our interest, but in theirs. . that works ardently for the continual development of their imperfect society ... that does not restrict itself to exploiting them. ${ }^{, 59}$ But, Tocqueville admits, these sentiments are aspirations: statements of what ought to be "the permanent tendency and the general spirit of our government. ${ }^{, 60}$ When he turns to concrete details of French policy, even in this public report attempting to reassure its readers that France will of 
course act with humanity and justice, the true difficulty of maintaining a balance between "our interest" and "theirs" emerges.

\section{A public agenda for Algeria}

The problem of acquiring territory for European settlement—not just any territory, but "the most fertile, best-irrigated, best-prepared lands"-was perhaps the most difficult policy issue facing the French. ${ }^{61}$ Stubbornly attached to the American analogy, Tocqueville argues that Algeria was sparsely settled by peoples who, if not true nomads, were still "mobile" and had not developed settled agriculture. Thus there was room for French settlement. ${ }^{62}$ Although he warns against "deceitful or derisory transactions" (the clear reference here is to the Americans' duplicitous treatment of the Indians), against confiscation without indemnity, and against expulsion from the land, he still thinks it is possible to gain access to land "either in concessions of rights, or in an exchange of lands. ${ }^{63} \mathrm{He}$ is referring here to the practice that he had mentioned in his letter to Lamoricière, that is, inviting Arabs to cede lands to the French state that they did not "need," in exchange for recognition of their individual or collective ownership of lands it allowed them to keep. Known as "cantonnement" (delimitation), such a policy was in fact pursued by the French and was deeply resented by the Arabs as unjust. In practice it rapidly did turn into a policy of "refoulement" (expulsion from territory), helping to reopen an era of insurrection in 1859, the year of Tocqueville's death. ${ }^{64}$

A second issue was how to make the goal of "working ardently for their development" more than empty rhetoric in a society structured around inequality. At the very least Tocqueville thought the French needed to address the damage they had done to Arab society. He recommends a modest rebuilding of the Muslim educational and 
charitable institutions, but warns against going too far in that direction. ${ }^{65}$ Next the French must abstain from interfering in Muslim religious institutions or civil law, which would dishonor the peace they had made with the indigènes. Tocqueville foresaw the creation of a permanently segregated society, and was opposed even to admitting young Arabs to French schools, since it would be "as dangerous as it would be useless to seek to suggest to them our mores, our ideas, our customs. ${ }^{, 66}$ Indigenous society, then, should be pushed only in the "direction proper to it." By this phrase, Tocqueville seems to mean that any voluntary movement toward European notions of individual property and labor should be encouraged, and that Arabs should be able to sell their labor to Europeans. "The European needs the Arab to make his lands valuable; the Arab needs the European to obtain a high salary." ${ }^{, 67}$ It is hard to see how this "community of interests" (a sort of internal guest worker policy) could be expected to reconcile the Arabs to the French presence, especially since it was combined with exclusion from the political community. Tocqueville is quite clear that the Arabs were to be governed from above, that is, would be granted no civil guarantees beyond the provisions of Muslim civil law and no political rights. He thought it would be suicidal for the French to forget that the Arabs' war-like nature and legitimate grievances made them a formidable potential military threat; the Arab indigènes must be ruled by what amounted to a law of exception, and subject to summary imprisonment or exile. ${ }^{68}$

The Kabyles (Berbers) posed a different problem. Settled agricultural peoples ensconced in mountain areas and fervently attached to the soil, they could be brought within the French orbit by a hands-off policy. One certainly shouldn't try to civilize them. In a dig at philanthropic civilizers, he noted that if you traveled to a Kabyle village to 
"speak about morality, civilization, fine arts, political economy, or philosophy," "they would assuredly cut off your head. ${ }^{, 69}$ The Kabyles were not a threat to French colonization, as long as their lands weren't confiscated or directly attacked. Tocqueville always vehemently opposed expeditions into Berber territories, which he thought foolish and unnecessary. If not attacked, the Kabyles would be peaceful trade partners and would accept living in the dominant orbit of the French as they had accepted the hegemony of the Turks.

\section{Private doubts}

The dreaded example of American crimes against the Amerindians-expulsion and extermination - was frequently invoked in French debates about relations with the North African indigènes. In both public and private, Tocqueville strenuously denied that he or the French government had any such intentions, and there is no reason to doubt his sincerity. Nevertheless, Tocqueville thought that a very likely effect of prolonged contact between the "civilized" French and the "barbarous" Arabs would be to demoralize and dispirit the latter through no one's explicit intention. ${ }^{70}$ In his Essay on Algeria, never intended for publication in its unrevised state, he notes that those who have been to Algeria "know that this state of things seems to become more so every day, and that nothing can be done against it. The Arab element is becoming more and more isolated, and little by little, it is dissolving. The Muslim population always seems to be shrinking,

while the Christian population is always growing." "71 Tocqueville's version of "lifting [the Arabs] in our arms toward well-being and enlightenment," then, seems restricted to allowing them to live in well-policed proximity to European commercial civilization, a 
contact from which he hoped rather vaguely that they would eventually profit, but which he believed was much more likely to produce demoralization and democratic decline.

In 1846 Tocqueville had a telling public and private interchange with his friend and usual political ally, Francisque de Corcelle. A strong supporter of the conquest, Corcelle had turned a blind eye to the morally troubling slash and burn policies that brought success because he—like Tocqueville — had come to the conclusion that only by such policies would France ever defeat the Arabs. Corcelle, however, became alarmed at rhetoric in the colonial press that called for the extermination of the Arabs. In a long speech in the Chamber, he argued that having achieved military victory, the French now faced the urgent question of the treatment of the indigènes. Indeed he was a more active civilizer than Tocqueville, holding out modest hopes for conciliation and conversion of the Arabs by extending French law (which Tocqueville opposed) and by attracting Arab "colonists" to new villages (a process known as internal colonization). Increasingly religious, Corcelle also was more hopeful of eventual Christianization. He was even willing to consider supporting military colonization-Tocqueville's bête noireprecisely because he had become convinced that the army might be necessary in the countryside to protect the indigènes from settler violence.

In public Tocqueville replied to Corcelle by misrepresenting his speech as a utopian hope to hold Algeria with the willing support of the Arabs. (Corcelle interjected, "I said nothing of the kind!" $)^{72}$ In private he acknowledged to Corcelle that the moral issue of what to do with the indigènes was very important, but establishing and protecting the European colony had to be the priority. In addressing Corcelle's fears that extermination would be the result of French policies, Tocqueville asserts that to push for 
the disappearance of the Arabs is cruel, absurd, and impractical. He adds, however: "but what should be done so that the two races enter into contact with one another? I confess with chagrin that here my mind is troubled and hesitates." ${ }^{, 73}$ Even more frank in a letter to Laromicière, he says that his own experience and his study of history have shown that when conquerors are both more civilized and stronger, they do not assimilate the conquered, but destroy or expel them. He ardently hopes the French will do better, but has little expectation of it. ${ }^{74}$ The decline or disappearance of the Arabs in Algeria, like the Indians in America, then, is not something to be wished for, but it is something that may be over determined. Tocqueville's conscience troubles him at the thought because he realizes that this decline of the Arabs would conveniently remove their threat to the colony and solve a thorny problem for the French. Since such a wish is criminal, it must be resolutely repressed.

\section{Final thoughts: The Sepoy Rebellion}

Although Tocqueville says almost nothing about Algeria after 1849, he does revisit the question of European imperialism in a series of letters about the Sepoy Rebellion in 1857 and 1858. Estranged from his own imperial government and just home from a triumphant trip to England after the publication of L'Ancien régime et la révolution, Tocqueville was as well disposed to his "second homeland" as he ever would be. ${ }^{75}$ His letters to English correspondents strike a uniformly sympathetic note of the following sort: your problems are our problems; my thoughts are with you in your hour of need, as should be those of all right-thinking Europeans! During the rebellion, he commiserates that English withdrawal from India would "be disastrous for the future of civilization and the progress of humanity." 76 After the British have regained control, he 
calls the British triumph a "victory for Christianity and civilization., ${ }^{, 77}$ But why exactly would British defeat have been a disaster, and what sort of victory had been won? I do not believe that Tocqueville thought that the calamity averted was the loss of British tutelage in India, or that the victory gained was the eventual Christianization and civilization of the Indian peoples. Rather a withdrawal from India would have been a great blow to English prestige and would have put in doubt the possibility of "civilized" imperial rule in general. ${ }^{78}$ Civilized and humanitarian nations should be able to rule backward peoples more successfully and humanely than did semi-barbarous conquerors like the Turks. Though, like all conquerors, they have to depend to some degree on force and fraud, they can also bring to bear technical superiority, administrative regularity and fairness, and the moral suasion exerted by a higher level of civilization. To abandon India would be to undermine the European claim to a superior technical and moral civilization (a claim in which Tocqueville believes passionately and proudly) and to bring shame on civilization by exhibiting cowardice in times that call for steady resolve. Abandoning India would also, of course, produce collateral damage: discrediting the sole liberal state among the European great powers and destabilizing international relations, as well as endangering French rule in Africa.

This whole episode, however, also causes Tocqueville to rethink his previous judgment that English rule in India constituted a successful model of rule as "better Turks." He now looks at English policy for mistakes rather than for positive lessons. Their very mildness allowed nationalism to grow and to swell into rebellion. At the same time they antagonized native elites through their haughty exclusivity. In fact, the English no longer look all that superior to the French. Moreover, Tocqueville now appears to be 
more sensitive to the problem of indigenous elites who are treated as foreigners in their own land. After reading Reeve's long piece about India in the Edinburgh Review of January 1858, an essay that proposes the introduction of a large English population into India, Tocqueville protests that such colonization would be a grave mistake that could only worsen England's particular problems. ${ }^{79} \mathrm{He}$ does not retract his support for colonization in Africa but does betray a heightened awareness of the connection between a European presence and native resentment, noting that the Arabs and Kabyles in Algeria resented colonists much more than soldiers. ${ }^{80}$ Moreover, thickly populated and agricultural, India was not a candidate for colonization or for the founding of a new society. The physical and moral issues of acquiring territory for settlement—difficult but not impossible in societies like North America and North Africa, according to Tocqueville - would be insoluble in India. Thus the English had no choice but to make a success of domination without colonization.

After the Rebellion Tocqueville assumes that successful domination (holding India with the tacit consent of indigenous elites) would require some basic reforms. He is forced to confront the issue that was implicit but muted in his earlier work on India: what did civilized England owe to her Indian subjects? While he repeats his judgment that the British have trumpeted a civilizing mission, but in a hundred years have done nothing to better the condition of their subjects, he is no longer content to pass over this hypocrisy with a few ironical comments. He now draws out the obvious inference. The English should have done better, and now must do better, or risk the loss of their empire. In a letter to Lord Hatherton, he notes "more could have been expected of them" than to have ruled like better Turks. ${ }^{81}$ 
What is the "more" that the British should have done? Their task was "not only to dominate India, but to civilize it. These two things, indeed, are closely connected." ${ }^{82}$ Tocqueville seems to be calling here for a form of domination that will gradually provide Indians access to economic opportunity. At the very least the exploitative East India Company, which deliberately ruined native industries and put its own commercial interests above the well-being of Indian subjects, should be replaced by direct rule under the eye of Parliament and the public. He writes to Ampère that the rebellion shows that

England must not only reconquer India, but govern in a new way. ${ }^{83}$ Tocqueville's correspondence with Reeve suggests that the new direction in British rule should focus on building an infrastructure of public works (roads, canals, and bridges) that will allow the country to become more self-sustaining and prosperous, with Indians eventually sharing in this development. Or, as he says to Lord Hatherton, "as the [British] government tends more and more to apply the general principles that make Europe rich and enlightened, it will little by little make the Indians feel the advantages of our civilization and will bring them closer to it." ${ }^{, 84}$ There is still, then, little taste for robust civilizing in the sense of transforming, educating, and moralizing a "backward" people.

\section{Conclusion}

Placing Tocqueville in the political landscape he inhabited allows us to understand why he succumbed to the temptation to ignore the claims of "imperfectlycivilized" peoples to a free way of life. To have acknowledged such claims, he thought, would have led inevitably to the humiliation of France, the weakening of the system of civilized states, and the loss of an opportunity to strengthen France's democratic political culture by engaging its citizens in a transcendent common purpose. He hoped that French 
dominance of the Arabs would be no worse than that of their own leaders or previous conquerors, and might eventually even improve their lot—if they survived the experiment. He resolutely repressed moral unease about violence—large and small—as a political burden that a statesman must bear. How accurate and insightful were Tocqueville's judgments about European imperial and colonial aims and policies? Like Tocqueville himself, who dissected and criticized the ideas and policies of French ancien régime and revolutionary statesmen from the perspective of the political culture they inadvertently created, we must in part judge him from the point of view of the postcolonial world we have inherited. From that perspective, we must acknowledge that despite his sometimes shrewd and far-seeing insights, his vision was blinkered and his choices often wrong.

Tocqueville saw quite clearly that European imperialists had by their own failures created reactive violence and stimulated the growth of new nationalist ideologies. But he never thought these animosities could be lessened by any form of shared governance; rather he believed that Europeans must rule in the manner of better Turks in order to contain these enmities and let them dissipate slowly in the mists of time. Although he resisted the impulse of French philanthropists to see the conquered peoples as clay to be shaped, he saw them largely as a threat to be managed and controlled, a threat that would naturally recede as Arab populations dwindled. Seduced by the American example, Tocqueville mistakenly believed that time was on the side of the French in Algeria. But the situation of two peoples inhabiting a common space without equity and parity unraveled along the seams that Tocqueville's own sensitivity to the dynamics of political struggle over status and honor would lead us to expect. And his policy choices 
contributed to this ominous result, helping to set France on the course that he feared.

Algeria did indeed become "a closed field, a walled arena, where the two peoples would

have to fight without mercy, and where one of the two would have to die." 85 Tocqueville

was warning against the moral disaster of expelling or destroying the Arabs, but

ironically it was French Algeria that died. The imperial voyage ended with the French

being driven out of Africa in a traumatic period of decolonization that ended as it had

begun: in debates over torture and atrocity. If Tocqueville was no more blind to this

future calamity than most of his contemporaries, those with a deep affinity for

Tocquevillean analysis have done him the honor of arguing that "more could have been

expected of him."

\footnotetext{
${ }^{1}$ Reflecting on the process of translating the critical edition of Democracy in America, James Schleifer notes the recurring images of being "struck" by an idea or event and of witnessing something "new" and important in America. See "Tocqueville's Democracy in America Reconsidered," The Cambridge Companion to Tocqueville, ed. Cheryl B. Welch (Cambridge: Cambridge University Press, 2006), 131-132.

${ }^{2}$ In "Did Tocqueville 'Get' America?” New York Review of Books 51 (29 April 29 2004), Gary Wills has perhaps taken the most extreme position on how little Tocqueville allegedly learned in America. Many other scholars, however, have debated the question of whether Tocqueville's European spectacles distorted what he saw, or whether what he observed caused him to grind a new set of interpretive lenses. The notes, variations, and outlines now made available to English readers in the Liberty Fund translation of the Nolla edition help us to see how far the latter is true, i.e., the extent to which Tocqueville's observations in America shaped his basic organizing ideas, and the extent to which he "got" America, even when he decided not to include what he had seen in the published text. As he notes in a first version of his Introduction, "I have not said everything that I saw, but I have said everything that I believed at the same time true and useful [v. profitable] to make known. .." Democracy in America : Bilingual edition in four volumes, ed. Eduardo Nolla, trans. James T. Schleifer (Indianopolis, Indiana: Liberty Fund, 2009) 1, 4. Hereafter cited as DA (Nolla/Schleifer) with volume and page.

3 "First Letter on Algeria" (23 June 1837) Alexis de Tocqueville: Writings on Empire and Slavery ed. and trans. Jennifer Pitts (Baltimore: The Johns Hopkins University Press, 2001), 5. [Unless otherwise indicated, future references to Tocqueville's writings on Algeria are to the Pitts translation.] Tocqueville refers here to Amedée Desjobert, the indefatigable critic of the conquest and colonization of Algeria, who had noted in the Preface to his La Question d'Alger (Paris: Dufart Librarie, 1837) that it was better to seek out the best research and the testimony of experts than to rely on vague and incomplete impressions of an isolated personal visit (vi-vii).
} 
4 "Intervention in the Debate over the Appropriation of Special Funding (1846)," 121.

${ }^{5}$ See Charles-André Julien, Histoire de l'Algérie contemporaine: La conquête et les débuts de la colonisation (1827-1871) (Paris: Presses Universitaires de France, 1964), 107-163.

${ }^{6}$ Steeped in the Greek and Roman classics, French military men frequently invoked the Roman conquest of North Africa in discussing the conduct of the war. Bugeaud noted that he was reviving the tactics of Metellus (mobile striking columns and razzia), that were tailored to the North African enemy. On the preoccupation with Rome, see Patricia M. E. Lorcin, "Rome and France in Africa: Recovering Colonial Algeria's Latin Past,"' French Historical Studies 25 (2002): 299-300.

${ }^{7}$ In 1843 a French captain wrote in letters home: "Grass no longer grows where the French army has set foot; ... [w] e scour the country, we kill, we burn, we carve up, we chop down, all for the best in this best of all worlds." Lucien-François de Montagnac to Célestine de Montagnac, 2 May 1843, Lettres d'un soldat: neuf années de campagnes en Afrique. (Paris, E. Plon Nourrit, 1885) 308. By 1848 it is estimated that over a tenth of the Arab population had been killed and the economy was in ruins. Raphael Danziger, Abd alQadir and the Algerians: Resistance to the French and Internal Consolidation (New York: Holmes \& Meier, 1977), xi.

${ }^{8}$ General Bugeaud called the military policies alleged to be necessary in Algeria (including infamous "enfumades" or the smoking of populations in caves) a different kind of legality, "brutal but logical." Quoted in Jean-Pierre Bois, Bugeaud (Paris: Fayard, 1999), 379. On this scorched earth warfare, see also Julien, Histoire de l'Algérie contemporaine, 177-178.

9 "Le ministère n'a pas fait coïncider sans dessein l'affaire d'Alger avec les nouvelles élections," Tocqueville wrote to his brother Édouard and sister-in-law Alexandrine, 24 March 1830, Euvres complètes, ed. J. D. Mayer, André Jardin, and Françoise Mélonio (Paris: Gallimard, 1951---) 14:60. [Hereafter cited as OC with volume and page.] The projected war, Tocqueville notes in a subsequent letter, is only « un coup de tambour, comme tu sais, pour tourner toutes les têtes. » Tocqueville to Edouard and Alexandrine, 6 April 1830, OC 14:64.

${ }^{10}$ Tocqueville to Edouard and Alexandrine, 6 April 1830, OC 14:65; cf. Tocqueville to Edouard and Alexandrine, 24 March 1830, OC 14, 60.

${ }^{11}$ André Jardin, Tocqueville: A Biography (1805-59) trans. Lydia Davis with Robert Hemenway. (London: Peter Halban, 1988), 319-320.

12 "Second Letter on Algeria" (22 August 1837), 24.

13 "Notes on the Koran" (March 1838), 27-35. Eventually Tocqueville became convinced that the religion of Mohammed was an impenetrable barrier to assimilation.

14 "Essay on Algeria" (October, 1841), 111. This work remained unpublished until it was included in Volume 3 of the OC in 1962. Soon after it was written Tocqueville passed it on to Beaumont, who at that time was planning a book on Algeria.

${ }^{15}$ Ibid., 70, 123, 127. Tocqueville's belief that France could not abandon Algeria without dishonor never wavered; see his claim in the "First Report on Algeria" (1847), 167-168: "Our preponderance in Europe, the order of our finances, the lives of part of our citizenry, and our national honor are engaged here in the most compelling manner."

${ }^{16}$ Unpublished letter of Tocqueville to Leon Faucher, 5 July 1840 [from Françoise Mélonio, to be published in a forthcoming volume of the OC.] I do not believe that Christian Bégin's portrait of Tocqueville as a reluctant colonizer and half-hearted supporter of the war, pushed into this position by 
French public opinion, can be sustained. See the largely exculpatory account in Bégin's "Tocqueville et l'Algérie," La revue Tocqueville/The Tocqueville Review 30:2 (2009), 179-203.

${ }^{17}$ Unpublished letter from Tocqueville to F. Buloz, October 2, 1840 [from F. Mélonio].

${ }^{18}$ Apparently he abandoned the work, he said much later, because "he would have had to go there in order to understand well what I wanted to talk about." Tocqueville to Lord Hatherton, 27 November, 1857, Alexis de Tocqueville: Selected Letters on Politics and Society, ed. Roger Boesche, trans. James Toupin and Roger Boesche (Berkeley, CA: University of California Press, 1985), 359. [Oeuvres complètes, ed. Gustave de Beaumont (Paris: Michel Lévy-frères, 1864-6) 6: 423. [Hereafter cited as OC (B).]

${ }^{19}$ Letter of Tocqueville to Francisque de Corcelle, 11 October 1846. OC 15:1, 218.

20 "Notes on the Voyage to Algeria in 1841," 36. Much of the evidence for Tocqueville's activities on this trip comes from a journalist's account. See Auguste Bussière, "Le Maréchal Bugeaud et la colonisation de l'Algérie, souvenirs et récits de la vie coloniale en Algérie," Alexis de Tocqueville, Oeuvres, Bibliotèque de la Pléiade, Vol. 1: 907-953. [Hereafter cited as EEuvres (P).]

${ }^{21}$ DA (Nolla/Schleifer) 1,3

${ }^{22}$ Jennifer Pitts, "Liberalism, Democracy and Empire: Tocqueville on Algeria," Reading Tocqueville: From Oracle to Actor, ed. Raf Geenens and Annelien De Dijn (London: Palgrave Macmillan, 2007), 18.

23 "Introduction: Tocqueville et la doctrine coloniale," De la colonie en Algérie, ed. T. Todorov (Paris: Editions complexe, 1988), 24-27; Stéphane Dion, "Durham et Tocqueville sur la colonisation libérale," Revue d'études canadiennes/Review of Canadian Studies 25:1 (Spring 1990), 60-77.

${ }^{24}$ See "The Dark Side of Tocqueville: On War and Empire," Review of Politics 67 (2005), 737-752. Melvin Richter initiated the discussion of Tocqueville's imperialism in "Tocqueville on Algeria." Review of Politics 25 (July 1963) 362-399. In the growing literature that addresses this tension, see especially the works of Jennifer Pitts: "Empire and Democracy: Tocqueville and the Algeria Question," The Journal of Political Philosophy 8:3 (2000) 295-318; "Introduction," Alexis de Tocqueville: Writings on Empire and Slavery, ix-xxxviii; A Turn to Empire: the Rise of Imperial Liberalism in Britain and France (Princeton: Princeton University Press, 2005),189-239; "Liberalism, Democracy and Empire: Tocqueville on Algeria," Reading Tocqueville, 12-30; and "Liberalism and Colonialism in Early Nineteenth-Century France," in Empire and Modern Political Thought, ed. Sankar Muthu, (Cambridge: Cambridge University Press, forthcoming 2012). See also Michael Hereth, Alexis de Tocqueville: Threats to Freedom in Democracy, trans. George Bogardus. (Durham, N.C.: Duke University Press, 1986), 145-165, Richard Boyd, "Tocqueville's Algeria," Society (September/October 2001), 65-70; Cheryl B. Welch, "Colonial Violence and the Rhetoric of Evasion: Tocqueville on Algeria," Political Theory 31:2 (April 2003), 247-257. and "Tocqueville on Fraternity and Fratricide," The Cambridge Companion to Tocqueville, 303-336; Margaret Kohn, « Empire's Law: Alexis de Tocqueville on Colonialism and the State of Exception, » Canadian Journal of Political Science 42 :2 (June 2008), 255-278. In French the literature is more sparse, but see Jardin, Tocqueville: A Biography, 316-342, Françoise Mélonio, "Nations et nationalismes, "La revue Tocqueville/The Tocqueville Review 19:1 (1997), 61-75 ; Seloua Luste Boulbina, "Présentation," Tocqueville Sur l'Algérie (Paris: Flammarion, 2003), 7-41; Jean-Louis Benoit, Tocqueville: un destin paradoxal (Paris: Bayard 2005), 264-279 ; and Bégin, “Tocqueville et l'Algérie."

${ }^{25}$ In his later writings on Algeria he settles uneasily on a different projected scenario, in which conquerors treat the conquered humanely without assimilation. See below for my discussion of the tensions in this view.

${ }^{26}$ I have explored some of these mechanisms of assuaging moral qualms in "Colonial Violence and the Rhetoric of Evasion." 
${ }^{27}$ See Seymour Drescher for the clearest articulation of Tocqueville and Beaumont's strategy of offering an independent alternative to what they characterized during the 1840s as Guizot's spineless pandering to England. Tocqueville and England (Cambridge, MA: Harvard University Press, 1964), 152-169.

${ }^{28}$ Beaumont had explicitly argued in a parliamentary report on the organization of civil law in the colony, "Algeria is comparatively as great an enterprise for France as India is for England," Ministère de la Guerre. Commission de colonisation de l'Algérie. Rapport fait au nom de la seconde sous-commission, par M. Gustave de Beaumont, le 20 juin 1842. Organisation civile, administrative, municipale et judiciaire. (Paris: Imprimerie royale, 1843), 40.

29 "Essay on Algeria," 59. Cf. the social economist Eugène Buret, who argued that if France abandoned the conquest she would-like Spain earlier-leave only "humiliating traces of her own powerlessness" in Africa. Question d'Afrique (Paris: Ledoyen, 1842), 35.

${ }^{30}$ Hugh Brogan, Alexis de Tocqueville: A Life (New Haven, CT: Yale University Press, 2006), 399.

${ }^{31}$ See the discussion by David Clinton, Tocqueville, Lieber, and Bagehot: Liberalism Confronts the World (London: Palgrave, 2003), 24-43.

32 The domination of India, Tocqueville argues, brings a "sentiment of greatness and power" to the whole people, and he notes that a conquest should be judged by other criteria than financial and commercial value. "L'Inde," OC 3:478.

33 "Introduction," Euvres (P)1, xxxiv.

${ }^{34}$ On the different levels of civilization among Europeans see DA 1 (Nolla), 257-258, note 19; Tocqueville speculates that Swiss federalism is difficult because of the differing levels of civilization of the cantons. See DA 1 (Nolla), 282 note $t$ and "Voyage en Suisse (1836)," Euvres (P), Vol 1, 631. Change to LF ed.

${ }^{35}$ See his letter to Henry Reeve, 12 April 1840, OC 6:1, 58. Cf. a much later letter to Gobineau, 13 November 1855, OC 9, 243: "[The Europeans] will be in another hundred years the transformers of the globe that they inhabit and the masters of their species. Nothing is more clearly announced in advance by Providence. If they are often, I admit it, great knaves, they are at any rate knaves to whom God has given force and power, and whom He has manifestly put for a time at the head of the human race."

36 "There are two ways to conquer a country: the first is to subordinate the inhabitants and govern them directly or indirectly. That is the English system in India. The second is to replace the former inhabitants with the conquering race. This is what Europeans have almost always done." "Essay on Algeria," 61.

37 “L'Inde,"OC 3:1, 458.

${ }^{38}$ Ibid., $505 ; 480$.

${ }^{39}$ Tocqueville to Louis de Lamoricière, 5 April 1846, Lettres choisies; Souvenirs, ed. Françoise Mélonio and Laurence Guellec (Paris: Gallimard, 2003), 561-567.

${ }^{40}$ Ibid., 563. [passage trans. Arthur Goldhammer].

${ }^{41}$ In a letter to Corcelles, Tocqueville acknowledges that the goal is to achieve domination analogous to the Turks: «cette domination à des conditions analogues à celle des Turcs est très praticable et qu'elle aurait lieu si, ce qui est possible, nous arrivons enfin à détruire Abd-el-Kader.»26 September 1840, OC 15:1, 151. See also "Essay on Algeria," 62, 65.

${ }^{42}$ It is painful to Tocqueville that the French bungled the initial conquest and have not really recovered from their mistakes. They dismissed anyone who knew how to administer the indigènes; they unsettled 
property rights; they antagonized the Arabs and threw them into the arms of new nationalist leaders. Rather than exploit the undisputed technical, administrative, and moral strengths of French civilization, the French squandered these advantages, thus necessitating a brutal war. "I returned from Africa with the distressing notion that we are now fighting far more barbarously than the Arabs themselves. For the present, it is on their side that one meets with civilization." "Essay on Algeria," 70. Cf. "First Report on Algeria," 141 and a letter of Tocqueville to his father, 23 May 1841, OC 14, 218-219.

43 "Notes Diverses sur la Colonisation de l'Algérie," OC 3:1, 289. Cf."Essay on Algeria," 65.

${ }^{44}$ Unpublished letter of Tocqueville to Lanjuinais 16 May 1841 [from F. Mélonio].

${ }^{45}$ The phrase appears in an unpublished letter to Léon Faucher 15 July 1841 [from F. Mélonio].

46 "Essay on Algeria," 90-93. For a discussion of the political economy implicit in his colonial writings, see Christian Bégin, "Tocqueville et l'économie politique," La revue Tocqueville/The Tocqueville Review 29:1 (2008) 202-205.

47 "First Report on Algeria," 148-149.

48 "Second Letter on Algeria," 25.

49 “Notes on Algeria," 57; cf. "Essay on Algeria," 101.

${ }^{50}$ Ibid., 78; "Second Report on Algeria," 153-54.

51 . "Notes on Algeria," 36.

52 "Essay on Algeria," 92.

${ }^{53}$ Ibid. What was necessary was a rational governing infrastructure, and Tocqueville was willing to envision a very firm metropolitan hand in its creation. "You do not perceive any powerful, central conception guiding it toward a common end and keeping each of the parts that compose it within their natural limits." "First Report on Algeria," 157.

54 “J'ai vu sous mes yeux les manières dont se peuplait l'Amérique du Nord. Quel grand exemple!" Tocqueville to Lamoricière 5 April 1846, Lettres choisies, 566-567.

${ }^{55}$ For example, see Sheldon Wolin, Tocqueville Between Two Worlds: The Making of a Political and Theoretical Life (Princeton, NY: Princeton University Press, 2001): "politics vitalized the whole society, transmitting its energies to civil society rather than reflecting the impulses coursing through civil society." (208, cf. 258).

${ }^{56}$ DA 1 (Nolla), 308; DA 2 (Nolla) 212. Cite LF edition.

57 "Essay on Algeria," 93, 98-105.

${ }^{58}$ Ibid.,111-112. Cf his letter to Jules Dufaure from Algeria of 6 November 1846, which complains of the "profound anarchy" that characterizes the civil organization of the colony. Lettres choisies, 568.

59 "First Report on Algeria," 142.

${ }^{60}$ Ibid., 145.

${ }^{61}$ Ibid., 139. 
${ }^{62}$ Tocqueville introduces this theme in the "Second Letter on Algeria," 24, and continues to reformulate it throughout his writings on Algeria. He also pursues the analogy between Amerindians and Arabs in his correspondence with Francis Lieber, even as Lieber tries to disabuse him of it. See Tocqueville to Lieber, 22 July 1846, OC 7, 109-112.

${ }^{63}$ First Report on Algeria, 143. In the unpublished "Essay on Algeria" he had admitted that it would never be possible to gain the land around Algiers without "violence," and that the Army and initial civilian rule had left property relations in such a mess that the state might have to use forced expropriation of contested territories (often held by land speculators) once and for all to fix titles. 87-88.

${ }^{64}$ See Charles-Robert Ageron, Modern Algeria: A History from 1830 to the Present, trans. and ed. Michael Brett (London: Hurst \& Company, 1990), 34-37. Even André Jardin, quite sympathetic to the imperialist Tocqueville, notes: “. . . the theory of cantonnement under which they [the tribes] were compensated with absolute title to part of the lands [they were forced to forfeit] would seem rather illusory." Second Report on Algeria," Note 4, 255. The future held many acts of despoliation that would be presented as progress. Tocqueville warned against some of them - such as allowing Muslim lands to be thrown onto the free market. By 1919 the Muslims had lost 18.5 million acres, and 98\% of lands in the Tell (the most favorable agricultural region) had been expropriated. See Benjamin Stora, Algeria 1830-2000: A Short History, trans. Jane Marie Todd (Ithaca, NY: Cornell University Press), 6-8.

${ }^{65}$ Apparently Tocqueville wished to be even more severe about the excessive generosity of the French towards the Arabs, especially with regard to military favors bestowed on Algerians, but was dissuaded by other members of the Commission. See "First Report on Algeria," Note 22, 252.

${ }^{66}$ Ibid., 142. See also Jardin, Tocqueville: A Biography, 335.

67 "First Report on Algeria," 145.

${ }^{68}$ Cf. Beaumont's Rapports, 2-7, which makes it clear that politically, Arab rights would be the same as those of foreigners; i.e he explicitly placed the indigènes under an unaccountable political regime that ruled by decree rather than law.

69 "First Letter on Algeria," 7.

70 "First Report on Algeria," 144.

71 "Essay on Algeria," 111. In fact, the Muslim population continued to decline during Tocqueville's lifetime. In 1830 there were probably around 3 million inhabitants; in 1851 the native population numbered not more than 2,324,000. In 1866 it was estimated at 2,652,000 but in the late 1860s declined again after a series of natural disasters (locusts, animal epidemics, drought). See Ageron, Modern Algeria, 4, 31, 44n.

72 "Intervention in the Debate over the Appropriation of Special Funding," 118.

${ }^{73}$ Tocqueville to Corcelle, December 1846, OC 15:1, 224.

${ }^{74}$ Tocqueville to Laromicière, Lettres choisies, 565-566.

${ }^{75}$ Drescher, Tocqueville and England, 188-192.

${ }^{76}$ Tocqueville to Henry Reeve, 2 August 1857, OC 6:1, 230

${ }^{77}$ Tocqueville to Lord Hatherton, 27 November 1857, Euvres (B) 6:422.

${ }^{78}$ See Tocqueville to Lady Thereza Lewis, 18 October 1857, Euvres (B) 6: 411-412. 
${ }^{79}$ Tocqueville to Henry Reeve, 30 January 1858, Selected Letters 362-364 [Cuvres (B), 6:426-430].

${ }^{80}$ Tocqueville to Lord Hatherton, 6 March 1858, CEuvres (B) 6:434.

${ }^{81}$ Tocqueville to Lord Hatherton, 27 November 1857, Selected Letters, 360. [Euvres (B) 6:423].

${ }^{82}$ Tocqueville to Lord Hatherton, 27 November 1857, Selected Letters, 360. [Cuvres (B) 6: 424].

${ }^{83}$ Toqueville to A. J.Ampère, 9 August 1857, in Cuvres (B) 6:404.

${ }^{84}$ Tocqueville to Lord Hatherton, 6 March 1858, CEuvres (B) 6: 434.

85 "First Report on Algeria," 146. 